\title{
The effect of dietary propionic acid on the requirement of chicks for vitamin $B_{12}$
}

\author{
BY R. RYS AND J. KORELESKI \\ Department of Animal Nutrition, Institute of Zootechnics, \\ Cracow, Sarego 2, Poland \\ (Received 4 December $1972-$ Accepted 27 June 1973)
}

\begin{abstract}
I. Test diets were given to chicks from I to $28 \mathrm{~d}$ of age. The basal diet contained soyabean meal as the sole source of protein and contained no vitamin $B_{12}$.

2. The basal diet supported poorer growth and feed conversion efficiency than did the same diet supplemented with $0.01,0.03$ or $0.3 \mathrm{mg}$ cyanocobalamin $/ \mathrm{kg}$.

3. Each of the four diets was also offered with a supplement of $20 \mathrm{~g}$ propionic acid $/ \mathrm{kg}$. This caused a significant growth depression at all but the highest level of cyanocobalamin addition.

4. Methylmalonic acid was detected in the excreta of chicks that received the supplements of 0 and $0.01 \mathrm{mg}$ cyanocobalamin $/ \mathrm{kg}$ diet, and in those of chicks receiving $0.03 \mathrm{mg}$ only for the chicks that were also receiving propionic acid.

5. The results suggest that giving the odd-carbon, propionic acid to chicks may increase their requirement for vitamin $B_{12}$.
\end{abstract}

It has been suggested that synthetic fatty acids used as dietary components for rats may have decreased their growth rate (Denel \& Hollman, I940; Williams, I947). In chicks given $\mathrm{C}_{\overline{5}}-\mathrm{C}_{9}$, short-chain synthetic fatty acids in their diet a small decrease in growth was also noted (Skotnicki, I97I). It has been found that the addition of vitamin $B_{12}$ could prevent the growth depression of chicks and rats that was observed when a diet deficient in vitamin $B_{12}$ was supplemented with propionate (Venkataraman, Biswas \& Johnson, I967; Dryden \& Hartman, I971). Fatty acids with odd-carbon numbers or with branched chains are metabolized through propionic acid to succinic acid. The presence of vitamin $B_{12}$ as a coenzyme of isomerase activity could be an important factor in propionic acid catabolism, conditioning the possibility of conversion of methylmalonic acid (Stadtman, Overath, Eggerer \& Lynen, I960).

Because of the possibility of the widespread use of propionic acid as an additive to reduce mould formation in cereal grain being stored before use in animal feeding, and also of the direct use of synthetic fatty acids in animal feeding, it is important to ascertain how far this compound can affect the requirement of animals for dietary vitamin $\mathrm{B}_{\mathbf{1 2}}$.

In the present paper we describe a study of the effect of dietary propionic acid on the weight gain and feed conversion efficiency of chicks receiving various levels of cyanocobalamin. The excretion of methylmalonic acid and the level of vitamin $B_{12}$ in the chicks' livers has also been investigated. 
Table I. Composition $(\mathrm{g} / \mathrm{kg})$ of basal vitamin $B_{12}$-free diet

$\begin{array}{lr}\text { Soya-bean meal } & 540 \\ \text { Glucose } & 408 \\ \text { Beef tallow } & 30 \\ \text { Vitamin, mineral and other supplement* } & 20 \\ \text { DL-methionine } & 2\end{array}$

* Supplied per kg diet: retinol equivalent $2.7 \mathrm{mg}$; cholecalciferol $55 \mu \mathrm{g}$; $\alpha$-tocopherol $8 \mathrm{mg}$; menaphthone $3 \mathrm{mg}$; riboflavin $4.5 \mathrm{mg}$; pyridoxine $0.4 \mathrm{mg}$; nicotinic acid $25 \mathrm{mg}$; calcium pantothenate $8 \mathrm{mg}$; folic acid I.2 $\mathrm{mg}$; choline chloride $0.45 \mathrm{~g}$; amprolium o.101 $\mathrm{g}$; oxy tetracycline $30 \mathrm{mg} ; \mathrm{FeSO}_{4} \cdot 7 \mathrm{H}_{2} \mathrm{O}$ I $50 \mathrm{mg} ; \mathrm{CuSO}_{4} \cdot 5 \mathrm{H}_{2} \mathrm{O} 7.9 \mathrm{mg} ; \mathrm{MnSO}_{4} \cdot 4 \mathrm{H}_{2} \mathrm{O} 300 \mathrm{mg} ; \mathrm{CoSO}_{4} \cdot 7 \mathrm{H}_{2} \mathrm{O}$ I.9 mg; $\mathrm{ZnSO}_{4} \cdot 7 \mathrm{H}_{2} \mathrm{O}$ I99 mg; $\mathrm{KI} 5.2 \mathrm{mg}$ and $\mathrm{CaHPO}_{4} \cdot 2 \mathrm{H}_{2} \mathrm{O} \times 7.5 \mathrm{~g}$.

\section{EXPERIMENTAL}

Animals. One hundred and twenty-eight hybrid Sussex $\times$ White Rock chicks were used, from I d old at the beginning to $28 \mathrm{~d}$ old at the end of experiment. The chicks were randomly assigned in pairs to each of eight dietary treatments, so that sixteen chicks (or eight pairs) received each diet. Each pair of chicks was housed in one cage; diet and water were given ad lib.

Diets. The composition of the basal diet is set out in Table $\mathrm{x}$. It contained no vitamin $\mathrm{B}_{12}$, and soya-bean meal (supplemented with methionine) was the sole source of protein. This diet was given to different groups with, in some instances, supplements of cyanocobalamin, propionic acid, or both, as set out in Table 2.

The weight gain and feed consumption of each pair of chicks were recorded. Droppings were also collected from each cage during the last $24 \mathrm{~h}$ of the experimental period, to measure the excretion of methylmalonic acid. From each treatment four chicks were then chosen at random and killed, and their livers were taken for vitamin $\mathrm{B}_{12}$ determination.

Chemical analysis. Methylmalonic acid was estimated in fresh droppings by a modification of the method of Dreyfus \& Dube ( 1967 ). Samples ( $80 \mathrm{~g}$ ) of droppings were diluted with $200 \mathrm{ml}$ distilled water and shaken for $30 \mathrm{~min}$, then stored for $24 \mathrm{~h}$ at $4^{\circ}$ before analysis. The amounts of methylmalonic acid were estimated by comparing the dimensions of the spots on the thin-layer chromatogram with those of the internal standard.

The vitamin $\mathrm{B}_{12}$ content of livers was determined microbiologically with Ochromonas malhamensis (Kawecka \& Ryś, Ig68).

Statistical analysis. All the results were statistically analysed by variance analysis and by the use of Duncan's multiple range test (Ruszczyc, 1970).

\section{RESULTS AND DISCUSSION}

The experimental results are presented in Table 2. With the basal diet used in this study, omission of the cyanocobalamin caused a significant $(P<0 \cdot 0 r)$ decrease in weight gain. Addition of propionic acid to the diet significantly $(P<0 \cdot 0 r)$ decreased weight gain in chicks given $0,0.0 \mathrm{I}$ and 0.03 cyanocobalamin $/ \mathrm{kg}$ diet but no effect was observed at the highest level of vitamin supplementation.

Similar results were obtained for the food conversion efficiency (FCE) but differ- 
Table 2. Effect of supplementing the basal, vitamin $B_{12}$-free diet with cyanocobalamin, propionic acid, or both, on weight gain, food conversion efficiency (FCE), methylmalonic acid content of droppings and vitamin $B_{12}$ content of the liver of chicks

\begin{tabular}{|c|c|c|c|c|c|}
\hline \multicolumn{6}{|c|}{ (Mean values for sixteen chicks/group) } \\
\hline \multicolumn{2}{|c|}{ Supplement to diet } & \multirow[b]{2}{*}{$\begin{array}{l}\text { Wt gain } \\
(\mathrm{g} / 28 \mathrm{~d})\end{array}$} & \multirow[b]{2}{*}{$\begin{array}{c}\text { FCE } \\
(\mathrm{g} \text { gain } / \mathrm{g} \text { food })\end{array}$} & \multirow[b]{2}{*}{$\begin{array}{l}\text { Methylmalonic } \\
\text { acid in } \\
\text { droppings } \\
\text { ( } \mu \text { g/chick per } d)\end{array}$} & \multirow[b]{2}{*}{$\begin{array}{l}\text { Vitamin } B_{12} \\
\text { content of } \\
\text { fresh liver } \\
\quad(\mathrm{ng} / \mathrm{g})\end{array}$} \\
\hline $\begin{array}{c}\text { Cyanocobalamin } \\
(\mathrm{mg} / \mathrm{kg})\end{array}$ & $\begin{array}{l}\text { Propionic } \\
\text { acid } \\
(\mathrm{g} / \mathrm{kg})\end{array}$ & & & & \\
\hline o & $\circ$ & $382 \cdot 0$ & $0 \cdot 3^{66}$ & 36 & $10 \cdot 0$ \\
\hline o & 20 & 2397 & 0.299 & 29 & $9 \cdot 5$ \\
\hline 0.01 & $\circ$ & $488 \cdot 0$ & 0.389 & 13 & $48 \cdot 2$ \\
\hline 0.01 & 20 & $407 \cdot 2$ & 0.367 & 13 & $46 \cdot 5$ \\
\hline 0.03 & 0 & $486 \cdot 6$ & 0.407 & ND & $26 \cdot 7$ \\
\hline 0.03 & 20 & $422 \cdot 8$ & 0.367 & 18 & $30 \cdot 2$ \\
\hline 0.30 & $\circ$ & $479 \cdot 4$ & 0.390 & ND & 10377 \\
\hline 0.30 & 20 & $497^{\circ} \mathrm{I}$ & 0.404 & ND & $1,31 \cdot 2$ \\
\hline \multirow{4}{*}{\multicolumn{2}{|c|}{$\begin{array}{l}\text { SE of mean }(56 \mathrm{df}) \\
\text { Significance of vitamin } B_{12} \\
\text { Significance of propionic acid } \\
\text { Significance of } \mathrm{V} \times \mathrm{P}\end{array}$}} & $4 \cdot 2$ & 0.017 & - & $4.9(3 \mathrm{I} d f)$ \\
\hline & & $* *$ & NS & - & ** \\
\hline & & $* *$ & $*$ & - & NS \\
\hline & & $* *$ & NS & $\ldots$ & NS \\
\hline
\end{tabular}

ND, not detected; NS, not significant; $* P<0.05 ;{ }^{* *} P<0.0$ r.

ences were not as evident. Addition of propionic acid significantly $(P<0.01)$ decreased FCE only in the absence of cyanocobalamin.

The determinations of vitamin $B_{12}$ content in liver showed that a dietary supplement of the vitamin markedly affected its content in this tissue; however, a supplement of $20 \mathrm{~g}$ propionic acid $/ \mathrm{kg}$ diet did not.

Excretion of methylmalonic acid in urine has been observed in vitamin $B_{12}$ deficiency states in man and other animal species (Geisler, Wahdati \& Henka, 1965; Green \& Pegrum, I968; Spray, Newman \& O'Brien, I969). In the present study methylmalonic acid was identified only in the droppings of chicks receiving diets containing $O$ and $0.01 \mathrm{mg}$ supplementary cyanocobalamin/kg and was not detected with those receiving higher levels.

It should be mentioned here that in this work the method used for estimating methylmalonic acid was only semi-quantitative because droppings and not pure urine were analysed. We cannot therefore conclude from the results shown in Table 2 that dietary supplementation with propionic acid affected the amounts of excreted metabolite for the diets containing $o$ and $o \cdot a r m g$ cyanocobalamin $/ \mathrm{kg}$. Only at the dietary level of $0.03 \mathrm{mg}$ cyanocobalamin $/ \mathrm{kg}$ can the addition of propionic acid be said to have given rise to excretion of methylmalonic acid, at a mean value of $\mathrm{i} 8 \mu \mathrm{g} / \mathrm{chick}$ per d.

This finding, together with the results for weight gain and FCE, might suggest that the levels of 0.009 and $0.02 \mathrm{mg}$ vitamin $\mathrm{B}_{12} / \mathrm{kg}$ diet recommended by the National Research Council (1960) and the Agricultural Research Council (1967), respectively, may not be enough to meet the requirements of chicks that receive propionic acid in their diet. Our observations are in accordance with the results of published experiments with chicks and rats (Venkataraman et al. 1967; Dryden \& Hartman, 
197I) and they suggest that the odd-carbon propionic acid can increase the requirement of the chick for vitamin $B_{12}$.

We are grateful to Dr K. J. Carpenter for his kind help in preparation of the manuscript.

\section{REFERENCES}

Agricultural Research Council (1067). The Nutrient Requirements of Farm Livestock. No. I. Poultry. London: Agricultural Research Council.

Denel, H. J. \& Hollman, S. (1940). F. Nutr. 20, 2 I 5 .

Dreyfus, P. M. \& Dube, V. E. (1967). Clinica chim. Acta $55,525$.

Dryden, L. P. \& Hartman, A. M. (197I). F. Nutr, Ior, 589.

Geisler, II. J., Wahdati, A. \& ITenka, R. A. (1965). 7. Lab. clin. Med. 66, 667.

Green, A. E. \& Pegrum, S. D. (1968). Br. med. F. iii, 59I.

Kawecka, A. \& Ryś, R. (Ig68). Acta agr. silv. Ser. zootech. 8, no. 2, p. 37.

National Rescarch Council ( 1960 ). Publs natn. Res. Coun., Wash. no. 827.

Ruszczyc, Z. (1970). Metodyka doświadczen zootechnicznych [Methods of Animal Experiments]. Warsaw: PWRiL.

Skotnicki, J. (I97I). Wydaw. wotasne Inst. Zootech. Krakow no. 258.

Spray, G. H., Newman, G. E. \& O'Brien, J. R. O. (1 969$)$ ). Br. J. Nutr. 23, 343.

Stadtman, E. R., Overath, P., Eggerer, M. \& Lynen, F. (1960). Biochem. biophys. Res. Commun. 2, I. Venkataraman, S., Biswas, D. K. \& Johnson, B. C. (1967). F. Nutr. 93, I31.

Williams, P. (1947). Chemy Ind. 19, 252. 